\title{
Economical Assessment Mineral Fertilizers Application Systems in Production Conditions
}

\author{
Vasilii Zhdanov ${ }^{1, *}$ Lubov Vinnichek $^{2}$ Maria Vizirskaya ${ }^{3}$ Ivan $_{\text {Zhdanov }}{ }^{1}$
}

\author{
${ }^{1}$ Moscow Aviation Institute, Moscow 125993, Russia \\ ${ }^{2}$ Penza State Agricultural Academy, Penza 440014, Russia \\ ${ }^{3}$ All-Russian Research Institute of Agricultural Chemistry named after D.N. Pryanishnikova, Moscow, 127550, Russia \\ *Corresponding author. vasilii.zhdanov@gmail.com
}

\begin{abstract}
In this article, there is an information about how the indicator of cost-effectiveness assessment can be calculated and evaluated depending on amount of plant nutrition required to achieve the value of planned yield. There are also some results of putting mentioned information into practice and some conclusions about the necessity of making corrections in existing fertilizer using system which are based on data that we obtained in the course of our research. Information presented in this article will be helpful for farms that are currently practicing the use of fertilizers in order to systematize research data which is already obtained.
\end{abstract}

Keywords: profitability of agricultural production, fertilizer using system, mineral plant nutrition, economic

efficiency

\section{INTRODUCTION}

If we look at average agricultural enterprises production costs, we will notice that up to $20 \%$ of total expenses per hectare is accounted for by the cost of the purchase of mineral fertilizers. Their use is one of the main ways to increase the production profitability as well as investing in improvements connected to plant protection products, production technology and seeds. The agricultural production in Russia made significant progress over the last 10 years [1]. Complex fertilizers began to be applied more actively, this also applies to sulfur fertilizers. Farms now pay more attention to technological issues of using agrochemicals (farm owners are now more attentive to selecting the most effective kinds of them according to existing conditions, as well as to choosing terms of their use, technique and technology of usage). But at the same time, there is no structured system of using agrochemicals which would be understandable and useful according to existing production conditions and which would be applied by all of the russian farms at once [2,3].

There are a lot of different ways to calculate the indicator of need in using plant nutrition. The most commonly used are: the balance calculation method for the planned yield, calculation for the planned yield increase, normative calculation method, calculation based on field experiments. All of the mentioned methods aren't complicated to use, but values that we generally get as a result of such calculations seem to be unreasonably high and not applicable in existing conditions which set a goal to increase profitability in the first instance. The following example will demonstrate how to use these calculations and how to apply them in existing conditions.

\section{MATERIALS AND METHODS}

In the article we make analysis based on trial results conducted in Stavropol region. The experimental field was characterized by chernozem soil (humus content $-5,1 \%$ (GOST 26213-91), mobile phosphorus 152 \pm 17 (GOST $26205-91) \mathrm{mg} / \mathrm{kg}$ and potash $99 \pm 11 \mathrm{mg} / \mathrm{kg}$ (GOST 2620591), soil pH (water extraction) - 7,02 (GOST 26423-85). Winter wheat was the cultivated crop (Bagira variety). Traditional analytical methods were applied for calculation required amount of nutrients and economical assessment fertilization systems.

\section{RESULTS AND DISCUSSION}

Fertilizer expenses analysis when the calculation of agrochemicals requirement for the planned yield increase is used. If we stick to this method of calculation, we should expect getting a result of calculation which will give us an idea of how much of additional plant fertilizer is needed to achieve the planned yield increase. Specifically, in this example we will make calculations keeping in mind that the planned yield increase is 2 tons/hectare. The amount of the main plant nutritional elements that are regularly used for getting an acceptable yield is $31.0 \mathrm{kgs} / \mathrm{ton}$ for nitrogen fertilizer, $10.7 \mathrm{kgs} / \mathrm{ton}$ for phosphate fertilizer, $24.8 \mathrm{kgs} / \mathrm{ton}$ for potassium fertilizer. The percentage of nutrients that are actually absorbed by plants is 0.7 for nitrogen fertilizer, 0.3 for phosphate fertilizer and 0.6 for potassium fertilizer. In according to this, we will get the following calculation result (kgs/ton) (Table 1$)$. 
Table 1 NPK required amount calculated on additional yield

\begin{tabular}{|c|c|c|}
\hline $\begin{array}{c}\text { The amount of nutrients as part of fertilizers which } \\
\text { is required for winter wheat to achieve a } 2 \\
\text { tons/hectare yield increase (if we don't use any } \\
\text { fertilizers, the productivity of land is } 5.5 \text { tons/hectare) }\end{array}$ \\
\hline $\mathbf{N}$ & $\mathbf{P}_{\mathbf{2}} \mathbf{O}_{\mathbf{5}}$ & $\mathbf{K}_{\mathbf{2}} \mathbf{O}$ \\
\hline 89 & 57 & 129 \\
\hline
\end{tabular}

The need in plant nutrients can be satisfied by applying one of a few different plant fertilizer programs. Some of these programs will be presented in the Table 2. To make it convenient to compare, we will calculate the consumption of fertilizers in according to an amount of fertilizers needed to get $1 \mathrm{~kg}$ of additional yield (that is how we will get a chance to choose the most effective program of using fertilizers). You will notice that Program \#1 seem to be the most effective since it predicts the lowest expenses connected to fertilizer purchase per $1 \mathrm{~kg}$ of wheat grains. Program \#1 suggests using ammonium nitrate (230 kgs), ammonium phosphate $(100 \mathrm{kgs})$ and potassium chloride (200 kgs). Method of calculation for the planned yield increase doesn't take into account soil's own fertility, that is why some estimated data appear to be too high (specifically in our example it applies to potassium). If we pay attention to a mineral fertilizer system which is practically followed in agriculture, we notice that $200 \mathrm{kgs}$ of saltpeter and $150 \mathrm{kgs}$ of ammonium phosphate are being actually used. Herewith, the yield indicator ranges from 7.2 to 7.6 tons/hectare (which is an average of 2 tons of the planned yield increase). Accordingly, the calculation data which was obtained as a result of applying any calculation method must be tested in real conditions by means of field experiments. There should be a chance to compare calculated data and practically acquired data - it means that results of a few different fertilizing programs should be tested. Such approach to working with data allows us to get the most reliable calculation results and to adapt the chosen calculation method to the conditions of a particular farm. The Table 2 below represents the amount of expenses in relation to the chosen mineral fertilizer program.

If we talk about calculation of unit costs per $1 \mathrm{~kg}$ of additional yield, we should highlight Program \#1 among others $(200 \mathrm{kgs} / \mathrm{hectare}$ of potassium chloride for basic plant fertilizing step, $100 \mathrm{kgs} / \mathrm{hectare}$ of ammonium phosphate for the sowing step, $230 \mathrm{kgs} / \mathrm{hectare}$ of ammonium nitrate for the top dressing step - in parts) - 3.8 RUB $/ \mathrm{kg}$, we should also pay special attention to a Program \#3 $(300 \mathrm{kgs} / \mathrm{hectare}$ of ammonium nitro phosphate 14-14-23 for seedbed preparation, $10 \mathrm{kgs}$ of it for the sowing step, $100 \mathrm{kgs} / \mathrm{hectare}$ of ammonium nitrate for the top dressing step) - 4.2 RUB/kg. In terms of agronomy, fertilizing soil with $400 \mathrm{kgs}$ of ammonium nitro phosphate in autumn time is a controversial decision, because there is a risk of soil washing which means that the generous amount of nitrogen will be washed out and useless. Also, there is a chance that we will get an excessive growth of wheat right before winter months and a reduced plant viability in spring as a result. But the Stavropol region is characterized by a small amount of precipitation. This fact gives us an opportunity to expect that this variant of soil fertilizing will work well. The results of implementation of the mentioned method of soil fertilizing during the field experiment is shown below:

Table 2 Fertilization systems calculation

\begin{tabular}{|c|c|c|c|c|c|c|c|c|}
\hline Indicators & $\overline{\mathbf{A N}}$ & NP 12:52 & 16:16:16 & 14:14:23 & $6: 20: 30$ & KCl & $\begin{array}{l}\text { The amount of } \\
\text { expenses for } \\
\text { realizing the } \\
\text { Program, } \\
\text { RUB/hectare }\end{array}$ & \begin{tabular}{|c} 
Expenses per 1 \\
kg of \\
additional \\
yield, \\
RUB
\end{tabular} \\
\hline $\mathrm{N}$ & 34 & 12 & 16 & 14 & 6 & & & \\
\hline $\mathrm{P}$ & & 52 & 16 & 14 & 20 & & & \\
\hline $\mathrm{K}$ & & & 16 & 23 & 30 & 60 & & \\
\hline Price per ton & 10700 & 21000 & 18100 & 18500 & 18900 & 14800 & & \\
\hline \multicolumn{9}{|c|}{ Calculation of the costs of using a mineral fertilizing program } \\
\hline Program \#1, kgs/hectare & 230 & 100 & & & & 200 & & \\
\hline $\begin{array}{l}\text { Expenses (Program \#1), } \\
\text { RUB/hectare }\end{array}$ & 2461 & 2100 & & & & 2960 & 7521 & 3,8 \\
\hline Program \#2, kgs/hectare & 100 & & 350 & & & 100 & & \\
\hline $\begin{array}{l}\text { Expenses (Program \#2), } \\
\text { RUB/hectare }\end{array}$ & 1070 & & 6335 & & & 1480 & 8885 & 4,4 \\
\hline Program \#3, kgs/hectare & 100 & & & 400 & & & & \\
\hline $\begin{array}{l}\text { Expenses (Program \#3), } \\
\text { RUB/hectare }\end{array}$ & 1070 & & & 7400 & & & 8470 & 4,2 \\
\hline Program \#4, kgs/hectare & 200 & & & & 250 & 100 & & \\
\hline $\begin{array}{l}\text { Expenses (Program \#4), } \\
\text { RUB/hectare }\end{array}$ & 2140 & & & & 4725 & 1480 & 8345 & 4,2 \\
\hline $\begin{array}{l}\text { Actually used program, } \\
\text { kgs/hectare }\end{array}$ & 200 & 150 & & & & & & \\
\hline $\begin{array}{l}\text { Expenses (actually used } \\
\text { program), RUB/hectare }\end{array}$ & 2140 & 3150 & & & & & 5290 & 2,6 \\
\hline
\end{tabular}


increasing of need in extra mineral fertilizers. It means that using lower amounts of fertilizers will decrease the effectiveness of their use. These calculations show us the importance of soil $\mathrm{pH}$ indicator control, of fertilizing and land reclamation works in accordance to existing soil conditions (farms should not use physically acid ammonium sulfate and ammonium nitrate for the acid soil).

Table 3 NPK required amount calculated by balance calculation method for low $\mathrm{pH}$ soil

\begin{tabular}{|l|l|l|}
\hline \multicolumn{3}{|c|}{$\begin{array}{c}\text { Required amount of plant nutrients for the planned } \\
\text { yield, pH indicator for the soil is } \mathbf{6}(\mathbf{p H}=\mathbf{6})\end{array}$} \\
\hline $\mathbf{N}$ & $\mathbf{P}_{\mathbf{2}} \mathbf{O}_{\mathbf{5}}$ & $\mathbf{K}_{\mathbf{2}} \mathbf{O}$ \\
\hline 162,9 & 150,2 & - \\
\hline
\end{tabular}
plant nutrients for the planned yield (for acid soil conditions, $\mathrm{pH}=6$ ) are presented in a Table 4 . As we can see, unfavorable $\mathrm{pH}$ indicator provokes the significant

Table 4 Fertilization systems calculation

\begin{tabular}{|c|c|c|c|c|c|c|}
\hline Indicators & $\mathbf{A N}$ & NP 12:52 & NP 20:20 & NP 18:46 & $\begin{array}{l}\text { The amount } \\
\text { of expenses } \\
\text { for realizing } \\
\text { the Program, } \\
\text { RUB/hectare }\end{array}$ & $\begin{array}{c}\text { Expenses } \\
\text { per } 1 \text { kg of } \\
\text { additional } \\
\text { yield, } \\
\text { RUB } \\
\end{array}$ \\
\hline $\mathrm{N}$ & 34 & 12 & 20 & & & \\
\hline $\mathrm{P}$ & & 52 & 20 & & & \\
\hline \multicolumn{7}{|l|}{$\mathrm{K}$} \\
\hline Price per ton & 10700 & 21000 & 12600 & 21000 & & \\
\hline \multicolumn{7}{|c|}{ Calculation of the costs of using a mineral fertilizing program } \\
\hline Program \#1, kgs/hectare & 400 & 300 & & & & \\
\hline $\begin{array}{l}\text { Expenses (Program \#1), } \\
\text { RUB/hectare }\end{array}$ & 4280 & 6300 & & & 10580 & 5,3 \\
\hline Program \#2, kgs/hectare & & & 700 & & & \\
\hline $\begin{array}{l}\text { Expenses (Program \#2), } \\
\text { RUB/hectare }\end{array}$ & 0 & & 8820 & & 8820 & 4,4 \\
\hline Program \#3, kgs/hectare & 350 & & & 300 & & \\
\hline $\begin{array}{l}\text { Expenses (Program \#3), } \\
\text { RUB/hectare }\end{array}$ & 3745 & & & 6300 & 10045 & 5,0 \\
\hline
\end{tabular}

If there is a need to know doses of fertilizers for the soil with $\mathrm{pH}$ indicator neutral value (all of the other parameters are the same), we should remember that the need in fertilizing will be much lower in comparison to an acid soil, because the soil with $\mathrm{pH}=7$ is characterized by high availability of natural nutrients for plants. The result of calculations is represented in a table below. Those are dosage values which appear to be the closest to doses values we've gotten during the field experiments. The Table 5 demonstrates the level of need in using fertilizers for a planned yield of winter wheal (the balance calculation method) in conditions of soil with $\mathrm{pH}$ neutral value [6].
Table 5 NPK required amount calculated by balance calculation method for soil with neutral $\mathrm{pH}$

\begin{tabular}{|l|l|l|}
\hline \multicolumn{3}{|c|}{$\begin{array}{c}\text { Required amount of plant nutrients for the planned } \\
\text { yield, pH indicator for the soil is } \mathbf{7}(\mathbf{p H}=7)\end{array}$} \\
\hline $\mathbf{N}$ & $\mathbf{P}_{\mathbf{2}} \mathbf{O}_{5}$ & $\mathbf{K}_{\mathbf{2}} \mathbf{O}$ \\
\hline 146,1 & 64,7 & - \\
\hline
\end{tabular}

Expenses needed for implementation of different programs of using fertilizers according to required amount of plant nutrients for the planned yield (for conditions of soil with $\mathrm{pH}$ neutral value) are listed in a Table 6. There are 3 
nitrogen and phosphorus, ammonium sulfate phosphate contains also sulfur which positively affects the yield and quality characteristics of the crop (we didn't pay attention to this fact during the field experiment). Prices for nitrogenphosphorus-sulfur-containing fertilizer are lower than prices for ammonium phosphate 12:52. Also, the availability to purchase the ammonium sulfate phosphate during the season is higher. These 2 facts are making the ammonium sulfate phosphate interesting as an alternative variant of soil fertilizing. characterized by a small amount of precipitation). Besides

Table 6 Fertilization systems calculation

\begin{tabular}{|l|c|c|c|c|c|c|}
\hline \multicolumn{1}{|c|}{ Indicators } & AN & NP 12:52 & NP 20:20 & $\begin{array}{c}\text { NP } \\
\mathbf{1 8 : 4 6}\end{array}$ & $\begin{array}{c}\text { The amount of } \\
\text { expenses for } \\
\text { realizing the } \\
\text { Program, } \\
\text { RUB/hectare }\end{array}$ & $\begin{array}{c}\text { Expenses } \\
\text { per 1 kg of } \\
\text { additional } \\
\text { yield, } \\
\text { RUB }\end{array}$ \\
\hline $\mathrm{N}$ & & & & & & \\
\hline $\mathrm{P}$ & 34 & 12 & 20 & & & \\
\hline $\mathrm{K}$ & & 52 & 20 & & & \\
\hline Price per ton & 10700 & 21000 & 12600 & 21000 & & \\
\hline \multicolumn{2}{|c|}{ Calculation of the costs of using a mineral fertilizing program } & & \\
\hline Program \#1, kgs/hectare & 400 & 100 & & & & \\
\hline $\begin{array}{l}\text { Expenses (Program \#1), } \\
\text { RUB/hectare }\end{array}$ & 4280 & 2100 & & & 6380 & \\
\hline Program \#2, kgs/hectare & 250 & & 300 & & & 3,2 \\
\hline $\begin{array}{l}\text { Expenses (Program \#2), } \\
\text { RUB/hectare }\end{array}$ & 2675 & & 3780 & & 6455 & \\
\hline Program \#3, kgs/hectare & 300 & & & 150 & & 3,2 \\
\hline $\begin{array}{l}\text { Expenses (Program \#3), } \\
\text { RUB/hectare }\end{array}$ & 3210 & & & 3150 & 6360 & \\
\hline
\end{tabular}

As it was said earlier, the calculation data which was obtained as a result of applying any calculation method must be tested in real conditions by means of field experiments. The first step before the beginning of field experiment is choosing the most economically viable programs of using fertilizers. If experimenter gets too high amount of the required fertilizer dose after making calculations, he can use a reduction coefficient for his field experiments $-0.6,0.8$ and 1 . He can do the same if he has a limited funding for making a field experiment. And of course, farm owner should choose the most effective program of using fertilizers at the end of field experiment. The other reason to use a reduction coefficient for reducing the estimated doses of fertilizers is a risk related to a climate zone where the farm is situated. The examples of such risk factors are:

- regular droughts (in cases when we realize that estimated planned yield indicator can be achieved only if there will be optimal soil moisture regime, but our region is characterized by the arid climate over the last 4-5 years),

- the chance of plants freezing or over sowing because of the low germination,

- unfavorable phytosanitary environment,
- temperature factors (too low or too high temperature, long winter etc).

The example of profitability calculation for the program of using mineral fertilizers is shown in a Table 7 . This program was prepared after making calculations and getting a result of a field experiment. Thereby, we took into account all of the confirmed indicators of land productivity (not just planned values) which were tested in conditions of real farm.

The comparison is made for the program that was used in farm $(150 \mathrm{kgs} / \mathrm{hectare}$ of ammonium phosphate and 200 $\mathrm{kgs} /$ hectare of ammonium nitrate), also for the program which suggests using of $100 \mathrm{kgs} /$ hectare of ammonium phosphate, $200 \mathrm{kgs} /$ hectare of potassium chloride, 230 $\mathrm{kgs} /$ hectare of ammonium nitrate, $400 \mathrm{kgs} /$ hectare of NPK fertilizer 14-14-23 and $200 \mathrm{kgs} / \mathrm{hectare}$ of ammonium phosphate - the calculation for a land productivity increasing is used (that's why this program does not take into account the natural potassium in soil), and also for the program which suggests using of $300 \mathrm{kgs} / \mathrm{hectare}$ of ammonium sulfate phosphate and $250 \mathrm{kgs} / \mathrm{hectare}$ of ammonium nitrate - the calculation for a planned yield is used. 
Table 7 The economical assessment of different fertilization systems

\begin{tabular}{|c|c|c|c|c|c|c|c|c|c|c|c|c|c|}
\hline \multirow[t]{2}{*}{ № } & \multirow[t]{2}{*}{$\begin{array}{l}\text { Name of } \\
\text { item }\end{array}$} & \multirow[t]{2}{*}{ Units } & \multicolumn{2}{|c|}{$\begin{array}{c}\text { Ammonium } \\
\text { phosphate, 1.5 } \\
\text { centners/hectare } \\
\text { before sowing seeds } \\
\text { + ammonium } \\
\text { nitrate, } 2.0 \\
\text { centners/hectare } \\
\text { for top-dressing } \\
\text { (control values) }\end{array}$} & \multicolumn{2}{|c|}{$\begin{array}{c}\text { Ammonium } \\
\text { phosphate, } 1 \\
\text { centner/hectare }+ \\
\text { potassium chloride } \\
\mathbf{2 , 0} \text { centners/hectare } \\
\text { before sowing seeds } \\
+ \text { ammonium } \\
\text { nitrate, } 2.3 \\
\text { centners/hectare } \\
\text { for top-dressing }\end{array}$} & \multirow{2}{*}{$\begin{array}{c}\text { The } \\
\text { differ } \\
\text { ence } \\
\text { betwe } \\
\text { en } \\
\text { test } \\
\text { value } \\
\text { s and } \\
\text { contr } \\
\text { ol } \\
\text { value } \\
\text { s } \\
\text { (incre } \\
\text { ase), } \\
\text { RUB. }\end{array}$} & \multicolumn{2}{|c|}{$\begin{array}{l}\text { Ammonium sulphate } \\
\text { phosphate, } 3.0 \\
\text { centners/hectare } \\
\text { before sowing seeds, } \\
2.5 \text { centners/hectare } \\
\text { of ammonium nitrate } \\
\text { for top-dressing }\end{array}$} & \multirow{2}{*}{$\begin{array}{c}\text { The } \\
\text { differ } \\
\text { ence } \\
\text { betwe } \\
\text { en } \\
\text { test } \\
\text { value } \\
\text { s and } \\
\text { contr } \\
\text { ol } \\
\text { value } \\
\text { s } \\
\text { (incre } \\
\text { ase), } \\
\text { RUB. }\end{array}$} & \multicolumn{2}{|c|}{$\begin{array}{c}14: 14: 23-2 \\
\text { centners/hectare } \\
\text { before sowing } \\
\text { seeds }+2 \\
\text { centners/hectare of } \\
\text { ammonium nitrate } \\
\text { for top-dressing }\end{array}$} & \multirow[t]{2}{*}{$\begin{array}{c}\text { The } \\
\text { differen } \\
\text { ce } \\
\text { between } \\
\text { test } \\
\text { values } \\
\text { and } \\
\text { control } \\
\text { values } \\
\text { (increas } \\
\text { e), } \\
\text { RUB. }\end{array}$} \\
\hline & & & $\begin{array}{c}\text { Product } \\
\text { ion } \\
\text { costs, } \\
\text { RUB. }\end{array}$ & $\begin{array}{c}\begin{array}{c}\text { Share } \\
\text { of }\end{array} \\
\text { expense } \\
\mathrm{s} \text { in the } \\
\text { net cost } \\
\text { structur } \\
\text { e, } \%\end{array}$ & $\begin{array}{c}\text { Product } \\
\text { ion } \\
\text { costs, } \\
\text { RUB. }\end{array}$ & $\begin{array}{c}\begin{array}{c}\text { Share } \\
\text { of }\end{array} \\
\text { expense } \\
s \text { in the } \\
\text { net cost } \\
\text { structur } \\
\text { e, \% }\end{array}$ & & $\begin{array}{c}\text { Productio } \\
\text { n costs, } \\
\text { RUB. }\end{array}$ & $\begin{array}{c}\begin{array}{c}\text { Share } \\
\text { of }\end{array} \\
\text { expense } \\
\mathrm{s} \text { in the } \\
\text { net cost } \\
\text { structur } \\
\text { e, } \%\end{array}$ & & $\begin{array}{c}\text { Produc } \\
\text { tion } \\
\text { costs, } \\
\text { RUB. }\end{array}$ & $\begin{array}{l}\text { Share } \\
\text { of } \\
\text { expens } \\
\text { es in } \\
\text { the net } \\
\text { cost } \\
\text { structu } \\
\text { re, \% } \\
\end{array}$ & \\
\hline 1 & $\begin{array}{l}\text { Salary and } \\
\text { payroll taxes }\end{array}$ & $\begin{array}{c}\text { RUB/ } \\
\text { hectare }\end{array}$ & 5240 & $19,8 \%$ & 5240 & $17,8 \%$ & 0 & 5240,00 & $19,0 \%$ & 0 & 5240,00 & $17,1 \%$ & 0 \\
\hline 2 & $\begin{array}{l}\text { Plant } \\
\text { protection } \\
\text { products }\end{array}$ & $\begin{array}{l}\text { RUB/ } \\
\text { hectare }\end{array}$ & 3135 & $11,8 \%$ & 3135 & $10,7 \%$ & 0 & 3135,00 & $11,4 \%$ & 0 & 3135,00 & $10,2 \%$ & 0 \\
\hline 3 & $\begin{array}{l}\text { Mineral } \\
\text { fertilizers }\end{array}$ & $\begin{array}{c}\text { RUB/ } \\
\text { hectare }\end{array}$ & 5290 & $20 \%$ & 8241 & $28,0 \%$ & 2951 & 6412,10 & $23,2 \%$ & 1122 & 9540,00 & $31,1 \%$ & 4250 \\
\hline 4 & Seeds & $\begin{array}{c}\text { RUB/ } \\
\text { hectare }\end{array}$ & 3200 & $12,1 \%$ & 3200 & $10,9 \%$ & 0 & 3200,00 & $11,6 \%$ & 0 & 3200,00 & $10,4 \%$ & 0 \\
\hline 5 & $\begin{array}{l}\text { Fuels and } \\
\text { lubricants }\end{array}$ & $\begin{array}{c}\text { RUB/ } \\
\text { hectare }\end{array}$ & 3003 & $11,3 \%$ & 2884 & $9,8 \%$ & -119 & 2884,00 & $10,5 \%$ & -119 & 2884,00 & $9,4 \%$ & -119 \\
\hline 6 & $\begin{array}{l}\text { Transportatio } \\
\mathrm{n}\end{array}$ & $\begin{array}{c}\text { RUB/ } \\
\text { hectare }\end{array}$ & 700 & $2,6 \%$ & 787 & $2,7 \%$ & 87 & 820,00 & $3,0 \%$ & 120 & 729,70 & $2,4 \%$ & 30 \\
\hline 7 & $\begin{array}{l}\text { Third-party } \\
\text { company } \\
\text { services }\end{array}$ & $\begin{array}{c}\text { RUB/ } \\
\text { hectare }\end{array}$ & 0 & $0,0 \%$ & 0 & $0,0 \%$ & 0 & 0,00 & $0,0 \%$ & 0 & 0,00 & $0,0 \%$ & 0 \\
\hline 8 & $\begin{array}{l}\text { Other } \\
\text { expenses }\end{array}$ & $\begin{array}{c}\text { RUB/ } \\
\text { hectare }\end{array}$ & 3450 & $13,0 \%$ & 3450 & $11,7 \%$ & 0 & 3450,00 & $12,5 \%$ & 0 & 3450,00 & $11,3 \%$ & 0 \\
\hline 9 & Fixed costs & $\begin{array}{c}\text { RUB/ } \\
\text { hectare }\end{array}$ & 2450 & $9,3 \%$ & 2450 & $8,3 \%$ & 0 & 2450,00 & $8,9 \%$ & 0 & 2450,00 & $8,0 \%$ & 0 \\
\hline 10 & $\begin{array}{l}\text { Winter } \\
\text { wheat net } \\
\text { cost }\end{array}$ & $\begin{array}{c}\text { RUB/ } \\
\text { hectare }\end{array}$ & 26468 & $100 \%$ & 29387 & $100 \%$ & 2919 & 27591 & $100 \%$ & 1123 & 30629 & $100 \%$ & 4161 \\
\hline 11 & $\begin{array}{l}\text { Winter } \\
\text { wheat net } \\
\text { cost }\end{array}$ & $\begin{array}{c}\text { RUB/ } \\
\text { hectare }\end{array}$ & 4183 & & 4224 & & 41 & 4060,50 & & $\begin{array}{c}- \\
122,8 \\
4\end{array}$ & 4340,80 & & 157,46 \\
\hline 12 & Yield & $\begin{array}{l}\text { centner/ } \\
\text { hectare }\end{array}$ & 70,3 & & 77,3 & & 7,0 & 75,50 & & 3,50 & 78,40 & & 8,10 \\
\hline 13 & $\begin{array}{l}\text { Gross yield } \\
\text { in bunker } \\
\text { weight }\end{array}$ & $\begin{array}{c}\text { tons/ } \\
\text { hectare }\end{array}$ & 7,03 & & 7,73 & & 0,70 & 7,55 & & $\mathbf{0 , 5 2}$ & 7,84 & & 0,81 \\
\hline 16 & $\begin{array}{l}\text { Gross yield } \\
\text { weight* }\end{array}$ & $\begin{array}{c}\text { tons/ } \\
\text { hectare }\end{array}$ & 6,3 & & 7,0 & & 0,63 & 6,80 & & 0,47 & 7,06 & & 0,73 \\
\hline 18 & Proceeds** & RUB. & 59157 & & 65048 & & 5891 & 63533 & & 4376 & 65974 & & 6816 \\
\hline 19 & Gross profit & RUB. & 32689 & & 35661 & & 2972 & 35942 & & 3253 & 35345 & & 2655 \\
\hline 20 & $\begin{array}{l}\text { Gross profit, } \\
\%\end{array}$ & $\%$ & $55,3 \%$ & & $54,8 \%$ & & $-0,4 \%$ & $56,6 \%$ & & $1,3 \%$ & $53,6 \%$ & & $-1,7 \%$ \\
\hline 21 & $\begin{array}{l}\text { Profitability } \\
\text { of } \\
\text { production, } \\
\%\end{array}$ & $\%$ & $123,5 \%$ & & $121,3 \%$ & & $2, \overline{2} \%$ & $130,3 \%$ & & $6,8 \%$ & $115,4 \%$ & & $-8,1 \%$ \\
\hline \multirow{2}{*}{\multicolumn{2}{|c|}{ Fertilizers }} & \multicolumn{3}{|c|}{ Chosen program of fertilizing } & \multicolumn{3}{|c|}{$\mathrm{KCl}$} & \multicolumn{3}{|c|}{$\begin{array}{l}\text { Ammonium sulphate phosphate } \\
20: 20\end{array}$} & \multicolumn{3}{|c|}{ NPK 14:14:23 } \\
\hline & & $\begin{array}{c}\text { Fertilize } \\
\text { r rate, } \\
\text { kgs/ } \\
\text { hectare }\end{array}$ & $\begin{array}{l}\text { Price, } \\
\text { RUB/kg }\end{array}$ & $\begin{array}{l}\text { Sum, } \\
\text { RUB }\end{array}$ & $\begin{array}{c}\text { Fertilize } \\
\text { r rate, } \\
\text { kgs/ } \\
\text { hectare }\end{array}$ & $\begin{array}{c}\text { Price, } \\
\text { RUB/kg }\end{array}$ & $\begin{array}{l}\text { Sum, } \\
\text { RUB }\end{array}$ & $\begin{array}{l}\text { Fertilizer } \\
\text { rate, kgs/ } \\
\text { hectare }\end{array}$ & $\begin{array}{c}\text { Price, } \\
\text { RUB/kg }\end{array}$ & $\begin{array}{l}\text { Sum, } \\
\text { RUB }\end{array}$ & $\begin{array}{c}\text { Fertiliz } \\
\text { er rate, } \\
\text { kgs/ } \\
\text { hectare }\end{array}$ & $\begin{array}{c}\text { Price, } \\
\text { RUB/k } \\
\mathrm{g} \\
\end{array}$ & $\begin{array}{l}\text { Sum, } \\
\text { RUB }\end{array}$ \\
\hline \multicolumn{2}{|c|}{$\begin{array}{l}\text { Ammonium } \\
\text { phosphate 12:52 }\end{array}$} & 150,00 & 21,00 & 3150,00 & 100,00 & 21,00 & 2100 & & & & 200,0 & 10,70 & 2140 \\
\hline \multicolumn{2}{|c|}{$\begin{array}{l}\text { Ammonium nitrate } \\
(\mathrm{N}-34 \%)\end{array}$} & 200,00 & 10,70 & 2140,00 & 230,00 & 10,70 & 2461 & 250,00 & 10,70 & $\begin{array}{c}2675 \\
00\end{array}$ & & & \\
\hline \multicolumn{2}{|c|}{$\mathrm{KCl}$} & & & & 200,00 & 18,40 & 3680 & & & & & & \\
\hline \multicolumn{2}{|c|}{$\begin{array}{l}\text { Ammonium sulphate } \\
\text { phosphate 20:20 }\end{array}$} & & & & & & & 300,00 & 12,60 & $\begin{array}{c}3780 \\
0\end{array}$ & 400,00 & 18,50 & 7400 \\
\hline \multicolumn{2}{|c|}{$\begin{array}{l}\text { Ammonium nitro } \\
\text { phosphate } 14: 14: 23\end{array}$} & & & & & & & & & & & & \\
\hline 22 & $\begin{array}{l}\text { Total, per } 1 \\
\text { hectare }\end{array}$ & $\mathbf{x}$ & $\mathbf{x}$ & 5290 & $\mathbf{x}$ & $\mathbf{x}$ & 8241 & $\mathbf{x}$ & $\mathbf{x}$ & 6455 & $\mathbf{x}$ & $\mathbf{x}$ & 9540 \\
\hline
\end{tabular}

$*$ Selling price $=9350$ RUB/ton

$* * \%$ of dead and living waste $=10 \%$

Complex fertilizers were used for a seedbed preparation. As for Program \#1, the ammonium phosphate was used while sowing and the potassium chloride was used for basic plant fertilizing step. Nitrogen fertilizers were used for the topdressing step - in parts, in the ratio 60\%:40\% of an active substance. 
The next step is source data analysis and choosing parameters which are the most important at a moment of making decision about using a specific program of fertilizing. Achieving planned parameters of land productivity and the quality of crop is the main goal of using a specific program of fertilizing. Then, farm owner should take a time to calculate the need in plant nutrients for a planned yield. There are few ways of calculating. Sometimes it is better to use a few different ways of calculating at once to get a chance to compare results of calculating and to find an average value for making a program of land fertilizing.

After we calculated the required amount of fertilizers for the planned yield and for getting an additional crop, we found 8 different variants of programs. Only 3 of them were taken for a field experiment (the selection criteria here is estimated expenses for a unit of additional yield).

As a result of a field experiment, we got a chance to operate with real yield indicators. Also, all of the needed economic indicators were calculated - there are enough of them to make a conclusion about the most effective program of using fertilizers (this was obvious after looking at the revenue indicator, or at the indicator of a difference between additional earnings and additional expenses).

Using of combination of calculations and experimental data analysis allows us to improve the existing programs of using fertilizers more effectively. Certainly, field experiments take much time and require some labor costs. Experimentator would need to take care of a preparation step, to control the process during the whole experiment time, to record all of the results and to analyse them later. But it's worth it. This way of choosing the program of fertilizing gives us a possibility to get the most reliable results and to make our own programs of using mineral fertilizers which would be adapted to a specific farm conditions as much as possible.

\section{REFERENCES}

[1] Volkova A.V., The Mineral Fertilizer Market, 2017

[2] Kidin V.V., Basics of Plant Nutrition, 2008

[3] Kidin V.V., Fertilizing System, 2011

[4] Sychev V.G., The Current State of Soil Fertility And The Main Aspects of Its Regulation, 2019

[5] Mikhaylova L.A. Agrochemistry: The Course of Lectures. Scientific Basis of The Use of Fertilizers For The Main Field Crops, 2015

[6] Lapushkin V.M., Horticulture nutrition and Fertilizer, 2016 